\title{
Administration of a Negative Income Tax
}

\section{William D. Popkin $\dagger$}

A recent Comment in this journal ${ }^{1}$ described the negative income $\operatorname{tax}$ (the NIT) as "the boldest and most seriously considered" proposal for restructuring our welfare system. The Comment outlined the defects of the current public assistance programs and proposed a model statute to implement an NIT plan. Most of the debate over the NIT has focused on theoretical economic and welfare goals. Yet many problems with the present welfare system can be attributed to difficulties encountered in administering provisions that are theoretically impeccable. Neither the Journal Comment nor other articles on the NIT ${ }^{2}$ have analyzed these problems and their implications in much detail. This article takes that focus. In a number of areas, the evaluation of these administrative problems leads to different solutions from those appearing in the Journal's Model NIT.

At present, the process of selecting those eligible for public assistance and calculating their grants involves welfare workers in administrative activity which has tended to frustrate welfare objectives. The discretion to determine eligibility and the concomitant responsibility impose a tremendous burden on the welfare workers. When combined with the poor's characteristic unfamiliarity with bureaucracies, this discretion often leads to lack of uniformity in the treatment of recipients, arbitrary decisions, and delays in the receipt of benefits. Furthermore, before the amount of assistance is determined, it is usually necessary to determine each beneficiary's needs and available resources. Welfare workers must therefore spend much of their time investigating each beneficiary rather than providing him with counseling services. Not only does investigating waste the welfare workers' training, but it encourages the workers to invade the beneficiary's privacy in order to inspect his belongings and ask questions about his income, net worth, and consumption habits.

There is a great danger that an NIT will simply reintroduce these administrative problems. However much it may resemble a tax, an

$\dagger$ Assistant Professor of Law, Indiana University School of Law. A.B. 1958, LL.B. 1961, Harvard University.

1. Comment, A Model Negative Income Tax Statute, 78 YALE L.J. 269, 270 (1968) [hereinafter cited as MODEL NIT].

2. E.g., Tobin, Pechman \& Mieszkowski, Is a Negative Income Tax Practical? 77 YAL: L.J. 1 (1967) [hereinafter cited as Tobin, Pechman \& Mieszkowski]. 
NIT is a welfare program and its clients will be former welfare beneficiaries. It is essential, therefore, that a negative income tax be designed to eliminate those aspects of public assistance which have led to administrative inefficiency and abuse.

\section{Gathering Information}

\section{A. Income}

An NIT will scale benefits on the basis of need. ${ }^{3}$ Thus all poor families will receive the full basic NIT allowance unless they have income. Their income will be subject to a special NIT tax rate, and their benefits reduced accordingly. With a 50 per cent tax rate, for example, each dollar of income will reduce benefits by 50 cents.

There are two general approaches to defining the resources which will reduce NIT benefits. The NIT tax base might simply be the regular income tax base; or a more comprehensive tax base might be adopted, 4 which might include some portion of accumulated net wealth. In the context of a welfare program for the poor a more comprehensive definition of income which would differ significantly from the regular tax base could include public assistance, ${ }^{\circ}$ social insurance, ${ }^{\circ}$

3. See Model NIT 294, 302; Tobin, Pechman \& Mieszkowski 3.

To illustrate, a hypothetical provision might provide a family of four consisting of a husband, wife, and two minor children with a minimum allowance of $\$ 2,000$, subject to a tax rate of 50 per cent on other income. Thus, all poor families of four will receive $\$ 2,000$ unless they have income. Each dollar of income will reduce benefits by 50 cents. Of course, different minimum allowances would be provided to houscholds of different sizes and we will modify this example to illustrate complicating factors where appropriate. The break-even point in this plan is income of $\$ 4,000$ since, at this level of income, the family stops receiving NIT benefits. Below $\$ 4,000$, the 50 per cent tax rate would not wipe out the entire $\$ 2,000$ minimum allowance. The welfare, work incentive, and budgetary implications of an NIT are not discussed in this article. They have been dealt with in detail in the Comment proposing a Model NIT.

4. There has been considerable recent controversy concerning a comprchensive tax base for the regular income tax. Bittker, $A$ "Comprehensix'c Tax Base" as a Goal of Income Tax Reform, 80 HaRv. L. REv. 925 (1967); Musgrave, In Defense of an Income Concept, 81 HARv. L. REv. 44 (1967); Pechman, Comprehensive Income Taxation: $A$ Comment, 81 HARv. L. REv. 63; Galvin, More on Boris Bittier and the Comprehensive Tax Base: The Practicalities of Tax Reform and the ABA's CSTR, 81 Hass. L. REv. 1016 (1968); Bittker, Comprehensive Income Taxation: $A$ Response, 81 H.Arv. L. REv. 1032 (1968).

Dean Galvin now seems to prefer the term "broadened tax base" in deference to Bittker's critique; see Galvin, Willis \& Robbins, Technical Session on Tax Reform, 22 Tax Law 30 (1968). The BTB has replaced the CTB. OTt \& Ort, Simulatios of Revenue aNd Tax Structure Implications of Broadening the federal Income tax BASE (1968).

5. Rev. Rul. 57-102, 1957-I Cuxr. BuLL. 26 (public assistance payments not taxable). This exclusion seems based on public policy, rather than an interpretation of the gift exclusion of INT. REV CODE of 1954, $\$ 102$ [hereinafter cited as IRC], in much the sane way that expenses are often not deductible for public policy reasons under IRC $\S 162$.

Of course, their inclusion in the tax base would be a relevant issue only if they were 
gifts from friends, relatives and private charities, ${ }^{7}$ payments discharging an obligation of support other than by a husband or former husband, ${ }^{8}$ scholarships, ${ }^{9}$ and imputed income such as the rental value of owner-occupied homes or the value of food consumed and grown on the farm..$^{10}$ In addition, deductions for interest ${ }^{11}$ and taxes, ${ }^{12}$ which would seriously concern poor people who buy on credit, own homes subject to property taxes, and live in jurisdictions with sales or income taxes, might be eliminated. There are, of course, numerous other exclusions and deductions allowed under the regular income tax which might not be allowed under a more comprehensive tax base. These include the exclusion of interest on state obligations, ${ }^{13}$ the percentage depletion deduction, ${ }^{14}$ the dividend exclusion, ${ }^{15}$ and the capital gains deduction $^{16}$; they are of lesser significance in the context of determining the resources of the poor. ${ }^{17}$

For several reasons, there is considerable sentiment in favor of using a comprehensive definition of income for NIT purposes, even if it is not adopted for regular income tax purposes. ${ }^{18}$ First, the objectives of a transfer payment program for the poor are obviously to help those with low incomes. On the other hand, income tax exclusions and deductions are often designed to provide economic incentives for those with high incomes, notwithstanding the fact that they increase the opportunities for personal consumption by the recipient of the tax benefit. It is more difficult to disregard the effect on personal consumption of an exclusion or deduction if the sole purpose of the program is to help individuals with low personal consumption than

continued as supplemental benefits after an NIT were adopted. See C. GreEN, NEGATIve TAXes aNd the POverty Problem 86-92 (1967); Tobin, Pechman \& Mieszkowski 14.16.

6. Rev. Rul. 55-652, 1955-2 Cum. Bull. 21 (unemployment compensation not taxable); Treas. Reg. § 161-11(b) (1965) (Social Security not taxablc).

7. IRC \& 102(a).

8. Support payments pursuant to a legal obligation are not taxable, unless the Code explicitly so provides as in IRC $\S 71$ in the case of a husband or former husband. $C$ f. Gould v. Gould, 245 U.S. 151 (1917).

9. IRC § 117 .

10. Helvering v. Independent Life Ins. Co., 292 U.S. $371,378.79$ (1934) suggests that such income is not "income" within the sixteenth amendment, although that view would probably not be adhered to today. If a corporation allowed an owner-shareholder to use a house as a residence, rental value would be taxed to the occupant. Chandler v. Commissioner, 119 F.2d 623 (3d Cir. 1941).

11. IRC \& 163 .

12. IRC \& 164 .

13. IRC \& 103.

14. IRC \$ 613 .

15. IRC \& 116(a).

16. IRC \$ 1202 .

17. For a more complete discussion of a broadened tax base, sec MODEL NIT 811-15.

18. C. GreEN, supra note 5, at 165-66; Tobin, Pechman \& Mieszkowski 11. 
if the effect on personal consumption is only one of several considerations. The transfer of $\$ 1,000$ from a taxpayer with $\$ 10,000$ of income to individuals with $\$ 3,000$ of tax-exempt income from interest might seem inappropriate, whereas refusing to tax individuals on such income for economic reasons, such as encouraging investments in municipal bonds, might not seem as serious.

Second, there is often little urgency in providing low income taxpayers with economic incentives for certain consumption or investment behavior through tax subsidies. Individuals with low incomes do not normally invest in tax-free bonds nor do they earn much on dividends or capital gains. The economic policies served by variations from a more comprehensive tax base under the regular income tax can, therefore, be served without subsidizing these activities when engaged in by low income beneficiaries. Of course, the higher the break-even point ${ }^{19}$ the more likely it is that the beneficiaries will become significant with respect to the economic policies inherent in the grant of exclusions and deductions under the regular income tax.

Third, explicit expenditures, such as the benefits paid under an NIT program, will not look the same to Congress as tax reductions, such as a deduction for an expense or an exclusion of a payment. These tax reductions do not enter into the budget. ${ }^{20}$ Thus, while tax reductions might be allowed to slip through unnoticed, expenditures will be closely scrutinized by interests competing for the funds. Of course, the poor who seek an NIT could point to the oil depletion deduction as an example of the oil industry receiving money which might otherwise be earmarked for an NIT program, and depletion deductions might be clearly recognized as the equivalent of a government expenditure. But NIT payments will probably have to compete with such government expenditures as farm subsidies, without regard to the existing tax benefits for the farm sector of the economy.21

While the effectiveness of these arguments is problematical, it does seem likely that there will be some expansion of the NIT tax base beyond that used for the regular income tax. Under current welfare

19. See note 3 supra.

20. There is considerable sentiment for treating exclusions and deductions under the income tax as budget items if they are intended to operate as subsidies. Surrey. The United States Income Tax System-The Need for a Full Accounting (Remarks Before the Money Marketeers, New York City, Nov. 15, 1967, Treasury Department Release). The Treasury has now published its idea of a tax expenditure budget. See Exhibit to 1968 SEC. TREAS. ANN. REP., reproduced at 7 CCH 1969 STAND. FEd. TAX REP. I G180.

21. For a discussion of the farm benefits inherent under present law, sec Hjorth, Cattle, Congress and the Code-The Dangers of Tax Incentives, 1968 WL. L. REv. Gil. 
laws, "income and resources" of the household offset benefits. ${ }^{22} \mathrm{Al}$ though there is no uniform interpretation of this phrase, it certainly embraces a more comprehensive definition of income and wealth than the limited definition of income under the regular income tax. ${ }^{23}$

The remainder of this section discusses the effect of administrative considerations on expanding the tax base. We want to know which items not included in taxable income under the regular income tax but often put forward as eligible for inclusion in a more comprehensive tax base might be excluded for administrative reasons. A major thesis of this article is that physical and psychological invasions of privacy are an unacceptable burden on welfare beneficiaries. Therefore, no item should be included in the NIT tax base if it is likely to perpetuate the invasions of privacy which are frequently involved in current welfare investigations. Another important consideration is the administrative expense incurred in determining the existence and amount of any item which is to be included in the tax base. Administrative expense might not be as important under an NIT as under the regular income tax, however, since the pressures for a more accurate determination of income and wealth might outweigh administrative difficulties in obtaining accuracy for the same reasons that a more comprehensive tax base might be considered appropriate.

\section{Taxation of Benefits, Gifts, and Other Payments}

Public assistance payments and social insurance benefits do not seem to present any more administrative difficulty than wages ${ }^{24}$ and should be taxed to NIT beneficiaries. These types of income are normally paid in cash on a regular basis to a great many people by a limited number of persons. The payors can easily report the amounts paid to the NIT administrator. Computers can effectively check these items by matching the reports of payor and payee. Of course, computer time is not costless. But, except for this cost, there seem to be no other obstacles to the inclusion of these items as income from an administrative point of view.

Gifts from friends and relatives, on the other hand, present all the

22. Social Security Act of 1935, 42 U.S.C. \& 602(a)(7) (1964) [hercinafter cited to as Soc. Sec. Act].

23. See Comment, Eligibility Determations in Public Assistance: Selected Problems and Proposals for Reform in Pennsylvania, 115 U. PA. L. REv. 1307, 1321-24 (1967).

24. We are concerned only with administrative considerations. Commentators scem to agree that payments based on need would not be taxed but payments in the nature of insurance or retirement benefits would be taxed. See Comment to \& 11, Moded NIT 315-21; Tobin, Pechman \& Mieszkowski 17 (1967). 
administrative difficulties noted above and should be excluded from the NIT tax base. If the donor is a friend or relative, he is unlikely to be willing to report the gift to the administration because it would decrease the benefits which the donee is receiving from the government. Nor can the donee normally be expected to report gifts since they are probably small, irregular, and not normally considered taxable income.

Moreover, it would be extremely difficult for an administrator to detect unreported gifts without undue invasions of privacy. A common audit technique to detect unreported income is to check a sample of those taxpayers who are in the suspected category. If income reporting by small businessmen or farmers presents compliance problems, small businessmen and farmers can be identified and audited on a sample basis. Individuals who receive gifts, however, are not members of a particular class of people. Therefore, only by auditing numerous randomly-selected individuals could the government hope to detect recipients of gifts and to deter others from not reporting gifts. The only effective way to determine if a particular person has received a gift which neither he nor the donor reports is through an analysis of the way in which he has disposed of his resources. If his expenditures and increases in net worth are in excess of reported resources, then he has failed to report some item. But the detection of expenditures and increases in net worth to determine whether gifts have been received can only be accomplished by determining how the family has spent its money; and an effective program to identify these amounts can only be accomplished by the physical and psychological invasions of privacy that we wish to avoid.

A final consideration militating against including gifts in the NIT tax base is the context in which disputes over the existence of gifts usually arise. Welfare administrators tend to presume that past gifts continue ${ }^{25}$ or even that resources of a friend or relative are available as gifts whether or not they actually are provided to the welfare recipient. The difficulty of proving non-receipt which this presents to the welfare recipient is often sufficient to dissuade him from pressing his claim. Informal presumptions of this sort are a convenient device by which a reluctant administration can limit the size of its relief rolls.

If gifts trom relatives are excluded, how should payments which

25. See, e.g., Indiana Public Assistance Manuat, \& IV-B-25, which creates a presumption that payments continue if made by relatives obligated to support the beneficiary until discontinuance is proven. 
discharge a relative's obligation of support be treated? The question arises only when the relative is not a member of the beneficiary's household; for if he were a member of the household, his entire income might be taxed at NIT rates in accordance with the principles discussed below. ${ }^{20}$ Unless a payment discharging an obligation of support is clearly identified by a court order or written agreement, it is as difficult to detect as a gift and the likelihood of informal administrative presumptions leading to improper denials of benefits is just as great. Therefore, only the payments by a spouse, former spouse, or parent which discharge an obligation of support should be taxed to NIT beneficiaries and then only if pursuant to a court order or written agreement. ${ }^{27}$

Including in the NIT tax base support payments of a spouse, exspouse, or parent which are easily detected has the advantage of reducing the disparity between taxing the income of a man who is a member of a household and taxing the support payments after a split of a household which results in the man leaving the family. Since the man's income is taxed at NIT rates if he is a member of the household, ${ }^{28}$ an exemption from the NIT tax base for support payments from a spouse, ex-spouse or parent who has left the house would provide an incentive to split the household. ${ }^{20}$ Gifts from private charities will probably not present the difficulties of detection noted in connection with gifts from friends and relatives and payments of sup. port obligations not pursuant to a court order or written agreement. These payments are often paid to beneficiaries as regularly as if they were wages. Such systematic cash payments by private charities could, therefore, easily be reported to the NIT administrators. But the problems of keeping records where gifts were dispensed irregularly would probably be considerable. And the difficulties of valuing gifts in

26. See p. 402 infra.

27. This is consistent with the regular income tax law which provides explicltly for income splitting only if there is a court order or written agrement. IRC \& 71 . It goes beyond the regular income tax law, however, in including payments for children in the beneficiary's income. See IRC § 71(b); Commissioner v. Lester, 366 U.S. 299 (1961).

28. See pp. 403-05 infra.

29. The requirement, often found in welfare laws, that the beneficiary must pursue judicial or other remedies against those obligated to support the family as a condition to receiving benefits has been rejected. See, e.g., Indina Public Assistance Manual, \$ IV-B-22 (reasonable effort to secure support payments is required). Since there is a forfeiture of benefits only if the beneficiary is not reasonable in his efforts, this require. ment would take time to determine compliance and would introduce another clement of administrative discretion which is subject to abuse. The thrust of an NIT is to minimize such administrative discretion where possible. Nothing, of course, prevents welfare workers from helping the beneficiary to obtain support payments; the forfeiture of benefits is simply not to be used to force this result. 
kind, such as food and clothing, are probably too great to justify their being reported to the NIT administrators. ${ }^{30}$ Therefore, gifts by private charities should only be taxed to NIT beneficiaries if they are regularly dispensed cash gifts.

Should scholarships be taxable? The tuition element of a scholarship should probably not be taxed to NIT beneficiaries since this tax benefit is intended to subsidize low income families; variance from the regular tax laws by including tuition in the tax base would severely hamper the goal which the exclusion of scholarships from income is designed to accomplish. Several factors also militate against including the living expense element of a scholarship in the NIT tax base. Living expenses at school will probably exceed those which would have been incurred at home. And only the amount of living expenses which equal those which would have been incurred at home should be taxed since only those amounts can be considered personal expenses of the family which are reimbursed by the scholarship. Since isolation of these amounts is too difficult a task, the entire scholarship should be exempt. ${ }^{31}$

Most deductible items which are not included in taxable income under the regular income tax, such as interest and taxes, would be administratively easy to include in the NIT tax base, since they are deductions from income which must be reported in order to obtain the benefit of the deduction. There is, therefore, no need for an elective ten per cent standard deduction under an NIT to eliminate the administrative burden of verifying claims of personal deductions by small taxpayers. ${ }^{32}$

One group of deductions replaced by the standard deduction under the regular income tax should not be excluded from the NIT tax base. A tax base which purports to be comprehensive will not lightly disallow a deduction for expenses to produce income. But under current law most employee business expenses are replaced by the standard

30. Compensation of this kind is taxable under the regular income tax; Treas. Reg. \$ 1.6I-2(d) (1965). However, certain exclusions from an emplojec's income are probably explained by the administrative diffeulty of detection and collection. See Rev. Rul. 59.58, 1959-1 Cum. But.. 17 (Christmas turkey).

31. The problem of isolating the element of normal living expenses in traveling ex. penses while away from home led to the deductibility of the entire expense of meals and lodging. H.R. REP. No. 350, 67th Cong., Ist Sess. I1 (1921).

32. The merits of encouraging home ownership for the poor by allowing property taxes and interest to be deducted is not discussed. Taxes might be provided for in determining the cost of living and, therefore, in setting the appropriate minimum allowance. although variations among tax burdens on the poor in different states will make it difficult to incorporate this element with any degree of accuracj. 
deduction if it is elected. ${ }^{33}$ Is this necessary in the case of NIT beneficiaries? The best approach would probably be to allow the deduction of such expenses rather than to allow an elective standard deduction since it is unlikely that many NIT beneficiaries would have such expenses to deduct as long as the tax break-even point were not too high. ${ }^{34}$

\section{Comparison with the Model NIT}

The Journal's Model NIT includes in the tax base "gifts, (cash or otherwise), support and alimony payments . . . in excess of a total of $\$ 50$ per year," ${ }^{35}$ except when received from a private charity. Payments from private charity are probably exempted from taxation on the as. sumption that they replace government payments to relieve need..$^{30}$ The Model NIT would tax scholarships, including tuition, on the theory that the burden can be avoided by not claiming the student as a dependent. ${ }^{37}$ This is a workable solution. NIT beneficiaries, however, must still incur expenses for the student when he returns home. The regular income tax strikes a balance favoring the family with a child receiving a scholarship by excluding the scholarship in deciding whether the father provides the student with over one-half of his support so that he may be claimed as a dependent. ${ }^{38}$ On balance, the policy of an NIT should be to favor exclusion of the full amount of the scholarship.

\section{Taxation of Imputed Income and Net Worth}

The rental value of owner-occupied homes is normally excluded from the tax base under the regular income tax because of administrative difficulties in determining rental value. It is certainly too difficult

33. IRC \& 62(2).

34. It is difficult to know precisely how many NIT returns would have decluctions for employee business expenses. Income statistics for 1966 yield the following data of uncertain import. About 33 million returns report less than $\$ 5,000$ income. U.S. TRE ASURY Dep't, Internal Revenue Service, Statistics on Income-1966, table 1. Of thesc, about 450,000 deduct employee business expenses which are deductible whether or not the standard deduction is elected. Id., table 24, col. 55; table 37, col. 55. Of the approximately 6 million returns under $\$ 5,000$ which show itemized deductions about 3.5 million show "other deductions," about 100,000 show child care, and about 100,000 show clucation expenses. "Other deductions" include employee business expenses but the dollar amount is only about $\$ 450,000$. $1 d$. 169 \& table 25 , col. 16. The figures on employec business expenses incurred by those electing the standard deduction are likely to be of a lesser magnitude. These figures suggest, but do not prove, that the administrative burden would be manageable.

35. MODEL NIT 311 (\$ 11(b)(4)).

36. See p. 392 \& note 24 .

37. MODEL NIT 311,318 (\$ 11(b)(10) \& comment).

38. IRC \& $152(\mathrm{~d})$. 
to estimate the actual rental value of each home. An alternative would be to estimate a net return on the value of the home which would approximate the inclusion of rental value in income. This appronch has the advantage of adjusting for the expenses to produce rental income, such as depreciation, interest, taxes, and repairs, which would have to be deducted from rental value to arrive at a net imputed income from the house. ${ }^{39}$ Under this estimation approach the value of the house must be determined, and, unfortunately, local property assessments are usually too inaccurate to be used. ${ }^{40}$ Perhaps original cost could serve as an approximation of property value; this figure is likely to be easily available since bank financing is commonly involved.

It is unlikely, however, that estimates of rental values would be meaningful for most of the families in an area unless administrators were to identify each community very precisely and make separate presumptive estimates for each community. The estimate would have to be a minimum value, not an average, to prevent overestimating the income of many individuals, unless each separate community for which an estimate was made was homogeneous. Using a minimum value might well make determining the imputed rental value hardly worth the effort, since such a small amount of income would be included in the NIT tax base.

Further difficulties arise when the impact of such administrative procedures upon poor people is considered. Since the poor often cannot obtain adequate credit through conventional banking institutions, many poor home owners "buy" their homes on installment land contracts, bond-for-deed arrangements, or purchase money mortgages." In many of these situations, the buyer may not have legal title to his home or even an equity of redemption until he has paid a substantial portion of the purchase price. To uncover these sales, which are often not publicly registered until title passes, the NIT administrators would have to cross-examine the recipient or initiate investigations into the recipients' financial affairs-practices which the NIT should not encourage. Furthermore, poor home buyers pay premium rates for the credit they do obtain; often the credit charge is incorporated into the

39. A presumptive technique to tax rental value of owner-occupied hoines vins in effect in the United Kingdom until the Finance Act of 1963. Sec World Tax Series. United Kingdom \& 9/4.1 and CCH BRTrISH TAX GuDE \& 1-201A.

40. Maxwell, Financing State and Local Governments 137-41 (1965).

41. See Chicago Cominission on Human Relations, Selung and Buying Reil. Estate in a Racially Changing Neighborhood 8-9 (1962); Illinols Legislative Commission on

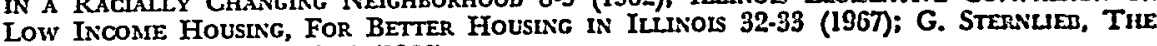
TENEMENT LANDLORD 114-16 (1966). 
sale price, resulting in prices 50 per cent above or even double the fair market value of the house. ${ }^{22}$ Imputing income on the basis of original cost would not accurately approximate the home's rental value and would be unfair to the NIT recipient. On balance, the difficulties in imputing rental income seem to outweigh any advantages. But since not many people own their own homes, the administrative burden of determining the rental value of their homes may not be as great as suggested.

The value of food grown and consumed on farms could be determined without examining the consumption behavior of individual farmers. Unlike gifts, however, it would be easy to determine the category of beneficiaries to be examined. Perhaps a satisfactory solution is to check a few farmers in each community in order to estimate the value of such food, without embarking on a widespread audit of the consumption patterns of all farmers. This estimated value of food grown and consumed on the farm would then be included in the NIT tax base, unless the farmer could refute the determination and prove the actual worth of the home grown food he consumed.

What kinds of wealth and how much of such wealth should be considered available as income under an NIT? One form of wealth could be included in the NIT tax base without any administrative difficulty. The return of capital in the receipt of periodic payments (which also include interest amounts) pursuant to Social Security or private annuity retirement plans is as easy to include in the tax base as wage payments. And excluding only that element of the payment which represents the return of capital might prove administratively difficult unless separate computations of this amount had already been made by the payor.

The administrative problems raised in considering other forms of wealth as partially available for consumption stem from the necessity of discovering the net wealth of the beneficiary. Some items of wealth could be determined without great difficulty, such as houses, cars, bank accounts, and stocks. Bank accounts and stock ownership could be reported to the NIT administrators by holders of such assets at the same time they report interest and dividends paid thereon. ${ }^{43}$ The ownership of houses and cars is normally recorded in a public place, such as the County Recorder's Office or the Bureau of Motor Vehicles.

42. See Chicago Commission on Human Relations, supra note 41, at 5.6; G. Stern. LIEB, supra note 41 , at 116,145 .

43. IRC \$\$ 6042, 6049 . 
Other possessions, however, can only be detected by having the beneficiary assess himself or by examining his consumption patterns or home in a way which is likely to involve invasions of privacy. Wealth statements filed by individuals are not a familiar part of our tax system and are not very effective except for property which is easy to detect anyway. ${ }^{44}$ Washing machines, coats, and television sets can only be detected by going into the home of a taxpayer.

One of the implications of these considerations is that, in order not to discriminate between such obvious forms of wealth as houses and less obvious forms of wealth such as consumer durables used in the house, net wealth should not be considered as available for consumption. But to prevent the rich man who failed to receive income in a particular year from receiving NIT benefits when he has available wealth which he can easily convert to cash, such as stocks, or on which he can easily borrow without any burden, such as a luxury house, some portion of net wealth over a generous exemption level should probably be included in the NIT tax base.45

\section{Comparison with the Model NIT}

The Model NIT includes in the tax base an imputed five per cent return on all gross capital, including both personal and income-producing property. ${ }^{46}$ The beneficiary is permitted to base his calculation on net capital alone if he will also include the interest paid on related indebtedness. Therefore, a taxpayer will prefer to include five per cent of gross capital in his income as long as interest rates exceed five per cent. The question is whether a five per cent imputed return is reasonable. As a realistic description of imputed income on personal property, it is surely too low if interest rates are higher than five per cent. No landlord would settle for a five per cent return on his gross investment if he had to pay more than five per cent for his capital. A more rational rate of return would be the Federal Reserve discount rate plus some specified percentage that properly accounts for both the rate of interest paid by landlords on mortgages in excess of the Federal Reserve discount rate and a normal rate of profit. The rate of re-

44. As of 1961, 83 per cent of locally assessed property taxes in the United States were imposed on realty. Maxwell, Financing State and Local Governsients, 134-37 (1965).

45. Tobin, Pechman \& Mieszkowski 18, suggest that the exemption level be eight times the minimum allowance. Houses owned by poor people vould probably be exempt under this rule.

46. MODEL NIT $321-22$ (§ 12). 
turn would not include a return of depreciation and maintenance expenses since in the case of personal property they are not deductible and have already been taxed. It might be argued that home owners are the primary group who will include imputed income in their NIT tax base and that a high imputed rate of return might force them to sell their homes to make ends meet. But, a realistic rate of return should represent the savings in rent that they enjoy, and a low estimate would discriminate in favor of a home owner in comparison with their neigh. bors who rent.

Since a minimum five per cent return is imputed to income-producing property as well as personal property, the Model NIT may have been reluctant to use a high imputed rate of return on property from which the taxpayer is not deriving income in the form of personal enjoyment. The technique of imputing income to unprofitable businesses, however, is only useful as an economic incentive to invest in more productive property. An NIT should avoid imposing penalties on beneficiaries with low income to encourage them to produce more. An NIT should seek to encourage productivity by limiting the tax rate on income to 50 per cent, not by imposing a burden on a taxpayer who does not realize income because he does not work or is inefficient. If the imputed rate of return is fixed without reference to the taxpayer with unproductive income-producing property, a major reason for keeping the rate low will be eliminated.

The Comment to the Model NIT also suggests that the five per cent return will prevent taxpayers with hobbies from receiving benefits. It is certainly appropriate to prevent taxpayers who engage in hobbies from receiving NIT benefits since a hobby is a highly productive consumption-producing activity, not an unproductive income-producing venture. The gross capital used in hobbies should be taxed, however, at the high rate applied to other personal property, not a low five per cent rate, and the expenses connected with the hobby should be treated as personal expenses. It will rarely, if ever, be necessary to utilize this approach under an NIT since taxpayers with hobbies will probably have other income pushing them above the tax break-even point. The suggested approach to hobbies, however, is more rational than either a five per cent imputed return on all gross capital as under the Model NIT or no imputed return at all and a deduction for the personal expenses attributable to the consumption-producing property to the extent of gross receipts, as under the regular income tax.

The gross capital on which the five per cent estimate is applied by the Model NIT is fair market value. Local property assessments are ap- 
parently expected to be useful, although it is recognized that estimates may be made. ${ }^{47}$ The Model NIT would tax the value of home grown food on the basis of estimates. ${ }^{48}$

The Model NIT includes imputed income from less obvious forms of wealth in the NIT tax base only if they exceed a certain minimum-for example, $\$ 4,000$ in the case of a family of four for clothing and consumer durables (apparently including cars, even though the administrative difficulty in determining ownership is minimal). Including an imputed return on property such as clothing and durables is likely to inspire administrative actions which will offend NIT beneficiaries, such as frequent investigations of their homes.

For a family of four the Model NIT exempts the $\$ 16,000$ of net wealth from the tax base. ${ }^{99}$ Since only net wealth is taxed this is probably high enough to exclude the homes of poor people. Consumer durables in the home and clothing are apparently included, however, in determining whether the exemption is exceeded. Since including such items is more likely to offer the NIT administrators an excuse to enter the home of NIT beneficiaries, it seems best to tax only wealth items whose ownership is publicly recorded, such as homes and cars, or items held by institutions which can be required to report ownership of assets held by them, such as banks and insurance companies.

\section{Summary}

Someone familiar with the administration of the regular income tax may have been wondering what all the fuss is about. After all, he might ask, the enforcement of income tax laws with respect to low income taxpayers is quite simple. Why should there be any difficulty under the negative income tax? We do not really know, however, how well our income tax laws are enforced at low income levels. Since most of the tax is collected by withholding from wages, ${ }^{, 0}$ it has never seemed wise to devote extensive resources to an examination of these taxpayers' incomes in view of the small return per taxpayer which this effort would bring. Only a very small percentage, usually under four per cent, ${ }^{51}$ of low income taxpayers are audited each year. And we do

47. MODEL NIT 328 (comment to $\$ 15$ ).

48. MODEL NIT 323 (comment to $\S 12$ ).

49. MODEL NIT 324 (§ 13(b)(4)).

50. For $1967,50.5$ of 69.4 billion dollars in individual income taxes was collected through withholding. 1967 Comm'R INT. REv. ANN. REP. 14.

51. 2.77 out of 72.2 million individual and fiduciary returns were audited; this is 
not know how much income goes unreported. The wages of domestic workers or persons with temporary odd jobs are often not reported by the payors because of the administrative headaches involved in filling out the forms and because such wages in the case of payments to domestic help may not be deducted. The percentage of unreported wages would probably be much greater with NIT beneficiaries than with regular income taxpayers. Furthermore, since the 50 per cent tax rate under an NIT would be much higher than under current law, the employee would have a much greater incentive not to report wages than under the regular income tax law. ${ }^{52}$

Since the NIT tax base will probably be more comprehensive than the regular income tax base, it is clear that our experience with low income taxpayers under the regular income tax is of doubtful help in predicting the administrative problems of an NIT. Occasionally an area involving complex administration of low income taxpayers does receive attention, such as the taxation of tips. ${ }^{53}$ But problem areas involving low income taxpayers generally receive inadequate attention from the Internal Revenue Service not only because of their expense in relation to the return per taxpayer, but also because the IRS does not wish to dissipate its public image by "going after" low income taxpayers.

It is probably true, therefore, that a well-administered NIT will be more complex and more expensive per individual than the administration of the regular income tax. Of course, this revelation comes as no surprise to welfare administrators who have long struggled to determine "income and resources" of the beneficiaries. Still, these complexities should never lead to the kinds of invasions of privacy which have plagued current welfare administration. It is not enough to shift to a declaration system which separates auditors from welfare workers. The job given to auditors must not be so designed that it can only be satisfactorily accomplished by reviving the investigative techniques

3.8 per cent. Since a much larger percentage of returns reporting at least $\$ 5,000$ of income are audited than returns with income under $\$ 5,000$, the figure for low.income taxpayers is certainly lower. 1967 COMM'R INT. REv. ANN. REP. 16, 23-24.

52. If the employee's tax rate is as high as 50 per cent, the cmployec might makc a deal with the employer to reduce his normal wages so that both employer and employec are better off than if normal wages had been reported. If the employer is in the 90 per cent bracket and is paying $\$ 10$ wages to an employee in the 50 per cent bracket, the employee might receive only $\$ 6$ unreported income and both employer and cmployee are better off than if the income is reported, a deduction taken by the employer and a tax paid by the employee.

53. See cases cited at 3 CCH 1968 STAND. FED. TAX REP. I 2767.1028. 
which have created so much dissatisfaction. "Income and resources" must be defined with this problem in mind.

\section{B. Determination of the Household Unit \\ 1. Definition of Needs and Identifying Household Members}

Under an NIT, the desire for precision in allocating benefits will probably lead to an attempt to determine benefits on the basis of the needs and resources of the entire household, assuming that there is an honest record of income and potential members of a household. ${ }^{-5}$ How can the needs of households of different sizes be defined, and how can the members of a household whose resources are to be considered in determining benefits be identified?

A quest for precision in the definition of need usually leads to the suggestion that the schedule of benefits for families of different sizes provide for a minimum allowance for each additional member of the family which is less than the allowance for a single-member household. For example, if a single-member household would receive an $\$ 800$ minimum allowance, the presence of a wife or child would result in additional benefits of less than $\$ 800$ per person. This suggestion reflects the received tradition, which is not without its critics, that incremental needs decline as the number in the household increases. ${ }^{.5}$

The desire for a precise identification of resources leads to the proposal that the income of all members of the household be aggregated to determine whether resources are available to meet needs. Thus, it would be unfair if all the members of one family were denied benefits because each member earned an equal share of an annual income of $\$ 4,500$, while another family received benefits because the wife and children earned nothing, even though the man alone earned $\$ 4,500$.

54. One problem, of course, is to assure that the members of a houschold reported on a return really exist. They might simply be fabrications intended to inflate the needs of the family. However serious a problem, false claims of this nature cannot be guarded against by substantive modifications of the NIT. They are a familiar part of our regular income tax administration and present no special problems in the context of an NIT. Thus, the main concern in this section is with the accurate definition of needs and resources.

55. Measuring incremental costs of married living is far from a precise endearor. It seems that two together can live more cheaply than two apart, which is the rationale for declining increments to the minimum allowance. However, if the comparison is between living as part of one's parents' family with life together as man and wife, this conclusion is not so clear. Furthermore, allowing any incremental costs for a wife might be ques. tioned if the comparison is between a bachelor who will be more likcly to purchase food at restaurants and pay for cleaning and laundry services and a married couple where the wife's services reduces these costs. See Oldman \& Templc, Camparative Analysis of the Taxation of Married Persons, 12 STAN. L. REv. 585 (1960) for a discussion of the different approaches to taxing married couples. 
The problem of defining a household to take account of economies of scale and pooling of resources is the most difficult problem in designing an NIT. A definition which focuses on the economic relationships among individuals would probably meet NIT objectives best. A household for NIT purposes should consist of persons who share resources under circumstances which evidence an implied com. mitment to share their resources for the future needs of the group. Focus on the economic unit is justified because an NIT is a welfare program and should, therefore, treat groups with equal resources equally to the extent that this is administratively possible.

A requirement that there be a relationship of mutual support excludes from the definition of a household any group which combines only to achieve economies of scale. For example, two roommates or two families who share a house and, perhaps, the expenses of food, should not be considered a household any more than lawyers who share rent and secretarial costs are partners. There is no implied commitment of resources of one individual or family to the future needs of the other individual or family, only a reduction of costs for the members of the group. It is true that individuals realizing economies of scale need less than others. But there are many opportunities for different households to reduce costs of living, and it would be unwise to reopen in every case the question of the level of need of a prospective beneficiary. One of the major advantages of an NIT is the fixing of an objective allowance schedule without regard to the opportunities for economizing which a welfare administrator might discern or consider appropriate in particular cases. The definition of a household as the economic unit involves enough administrative difficulty without expanding it to include measuring the economies of scale resulting from all joint efforts.

Some certainty can be introduced into the definition of an economic unit by treating the unmarried child as part of the household in which he resides in all cases. There are often legal and social limits on the use of a child's income for the household. These limits are not likely to prevail, however, among low income families, and the aggregation of the child's income with income of other members of the household is therefore justified. ${ }^{50}$

56. The logic of aggregating a child's income with the income of other members of the household is questioned in Bittker, Income Tax Reform in Canada: The Report of the Royal Commission on Taxation, $35 \mathrm{U}$. CHI. L. Rev. 637, 645.50 (1968). Under the regular income tax this pattern regarding differential needs and aggregation of resources is not followed. A husband and wife are taxed as though their income were recelved 
Several other possibilities have been rejected in deciding to define the household as an economic unit for NIT purposes. The definition of a head of household under the regular income tax, ${ }^{87}$ while closely related to the concept of an economic unit, is deficient in a welfare context. The rules have been developed under the regular income tax to relieve the taxpayer who provides financial help to others by reducing his tax rate rather than imposing a tax on the recipients of such help. For example, a man would qualify for head of household status if he lived in a home and provided more than one-half the cost of maintaining the household for a member of the household who is his unmarried lineal descendant or step-child. ${ }^{5 s}$ But the costs of maintaining a household, as defined by the Code, include only expenditures for housing and food and do not include the costs of other necessities. ${ }^{59}$ The man will qualify as head of a household in the above example, therefore, even if he does not provide more than one-half of the entire support of the member. ${ }^{00}$ If the member of the household is not an unmarried lineal descendant or step-child, however, the man would have to provide more than one-half the support. ${ }^{01}$ This statutory pattern seems designed to approximate the economic unit since it focuses on financial support. The omission of the requirement that the man provide more than one-half of the entire support in the case of unmarried lineal descendants and step-children is probably based on a presumption that the support is provided in those situations in any event. Such a presumption, however, is not justified in a welfare context where the effect would be to take the children off the NIT rolls, not reduce taxes. Payment of more than half the rent and half the food bills is good evidence that a relationship of support has

equally by two separate one-member houscholds, IRC $\S 2(2)$; the tax burden is not greater if the two taxpayers are husband and wife, rather than two single persons. Thus a husband and wife do not end up with less money after taxes than two single-member households whose aggregate income equals the total income of the husband and wife. And the deduction for personal exemptions for each child is the same as the deduction for the adult members of the family. IRC $\S \S 151(\mathrm{~b}), 151(\mathrm{c})(1)$. A critical appraikal of equal deductions per additional child appears in an excerpt from a 19.17 Treasury Department study, reported in S. SURREY \& W. WARREN, FEDERAL INCOAIE TAX 407-15 (1960).

Moreover, the income of the child and the father are not aggregated to determine tax obligations. For example, a family with $\$ 3,500$ earned by the father only pajs a $\$ 74$ tax, whereas if the father earned $\$ 2,900$ and the son was under 19 and carned $\$ 600$, there would be no tax. Not only is the income not aggregated, but the child reccives a deduction for his own personal exemption and the father also receives a deduction for the child if he provides over one-half of his support. IRC $\S \S 151(\mathrm{~b}), 151(\mathrm{c})(\mathrm{l})(\mathrm{B})(\mathrm{i})$.

57. IRC \& I(b).

58. IRC \& I(b)(2)(A)(i).

59. Treas. Reg. \& 1.1-2(d) (1956).

60. Treas. Reg. \& 1.I-2(b)(3)(1) (1956).

61. IRC \& 1(b)(2)(A)(ii); Treas. Reg. \& 1.1-2(b)(3)(ii) (1956). 
developed, but it should not be conclusive. Finally, the regular income tax denies a man head of household status if the household he seeks to establish includes a woman who is not his wife, relative, or in-law..$^{02}$

A completely different approach to defining a household is to focus on the legal status of marriage as the criterion. This approach should be rejected because marriage might be discouraged if it were to establish conclusively that a household exists. Furthermore, since the existence of a marriage does not preclude recognition of a split household under the regular income tax law, it should not prevent proof of a split household under an NIT. Separation is a recognized basis for splitting the taxable unit, and the need for a separation agreement as proof of separation under the regular income tax law is a bit of expensive sophistication not justified in a welfare program for the poor. Nor should the fact that the couple is not married conclusively cletermine that they do not form a household. The demise of the legal institution of common law marriages does not mean that the reality has disappeared. ${ }^{63}$

Welfare administrators long sought to resolve the definition of a household by resorting to a presumption that a man who cohabited with a woman was part of her household without regard to the length of his presence in the household, his legal obligation of support, his appearance to the community as a member of the same social unit as the woman and children, or his financial participation as a member of the same economic unit as the woman and children. The Supreme Court has now ruled that cohabitation is an insufficient criterion for household membership under the Social Security Law. ${ }^{61}$ It is still an open question under the Social Security Law, however, whether a legal obligation of support, membership in the same social unit, membership in the same economic unit, or some combination of these will make a man a member of the household. Federal regulations presently require as a condition for including children in the household that there be a legal obligation of support which is generally applicable to all children and not just to children on welfare. The regulations further limit potential membership in the household to fathers and step-fathers ceremonially married to the woman. ${ }^{05}$ A threejudge district court in California has held these regulations invalid

62. IRC \& $1(\mathrm{~b})(4)(\mathrm{B})(\mathrm{i})(1956)$.

63. H. Clark, Law of Domestic Relations $\$ 2.4$ (1968).

64. King v. Smith, 392 U.S. 309 (1968).

65. Soc. Sec. Reg. § 203.1(a)(b) (Aug. 8, 1968). 
and upheld a California law which includes a man in the household without regard to his legal status as a father or a step-father if he "is in or around the home" and he either represents himself to the community as a husband or father or assumes financial responsibility for the family. ${ }^{66}$ The California law makes such a man legally responsible to support the family only if the children are on welfare.

California seems to include a man in the household if he has both a legal obligation of support and he either forms a social unit with the woman and children because of his representation to the community or forms an economic unit with them by assuming responsibility for their financial well-being. The precise rationale of the federal regulations, on the other hand, is unclear. The requirement that the obligation to support the children be general and not limited to children on welfare might be designed to insure that the man is really considered by the community to be a member of the social unit. Limitation of membership in the household to fathers and step-fathers ceremonially married to the woman seems designed not to identify a man in the household but to eliminate some of the administrative abuses associated with identifying the role played by the man-in-thehouse.

As suggested, an NIT should not focus either on the social unit or the existence of a legal obligation of support, but on the economic unit. ${ }^{6 \tau}$ If the man is not a member of the economic unit, the remainder of the family does not share in his resources. Conversely, if he assumes financial responsibility for the family, his resources are available and he should be a member of the NIT unit to determine both needs and resources.

Similarly, a legal obligation to support the women and children should not be a condition for inclusion in the household under an NIT. If membership in the household were conditioned upon the existence of a legal obligation, the automatic exclusion of the man from the household in all other cases would discourage the development of more permanent relationships, since a legal obligation of support generally exists only in the case of fathers and step-fathers ceremonially married to the woman. A state might, of course, extend

66. Lewis v. Stark, Poverty Law Rptr. I 9299 (N.D. Cal. Dec. 23, 1968).

67. Membership of the man in the social unit including the woman and children might be a valid criterion for membership in the household under the Social Security Law which seeks to omit families from welfare who have a man-in-the-house if his social role is analogous to a father. King v. Smith, 392 U.S. 309, 329-30 (1965). An NIT, however, seeks to benefit economic units. 
the obligation of support to other men. Limiting membership in the household to cases where a legal obligation of support exists, however, is an irrational narrowing definition of households. Households should be determined on the basis of actual economic relationships, not on the happenstance of state-imposed legal obligations of support.

NIT administrators will face a difficult task in deciding whether a man is actually part of an economic unit. The problem is not merely in applying a difficult standard to ambiguous fact situations, but in dealing with beneficiaries who might be reluctant to cooperate. If an NIT provided for declining incremental benefits per additional member of the family and for aggregating the incomes of members of the economic unit, it would often be more advantageous for a family to appear to be split. For example, if the minimum allowance of a onemember household is $\$ 800$ and added members increase the allowance by $\$ 400$ per person, the family of four without income is entitled to a $\$ 2,000$ minimum allowance; but a household of one and a household of three are eligible for $\$ 800$ and $\$ 1,600$. Furthermore, if the man earns $\$ 2,500$ of income, he could avoid the 50 per cent tax rate on much of his income by posing as a single-member household. If the break-even point for a one-member household is $\$ 1,600$, assuming an $\$ 800$ minimum allowance and a 50 per cent tax rate, income over $\$ 1,600$ would not be taxed at 50 per cent. ${ }^{88}$ Agregation of the man's income with the income of the woman and children, however, results in the man's income being taxed at 50 per cent up to the break-even point for a four-member household, which is well over $\$ 1,600$. Thus the family obtains greater NIT benefits by appearing to be split.

The sensitivity of the investigation required to identify an economic unit can be appreciated by considering the questions which must be answered. To what extent must a person's privacy be invaded to determine whether absence of a man from a home is temporary, ${ }^{60}$ or whether payments by the man are large enough or regular enough, or sufficiently used for household purposes, so that they can be characterized as support by a member of the economic unit, not gifts or compensation? An NIT will have to be administered with considerable care in this area. ${ }^{70}$ Investigations to determine who are members

68. The father would have an option to be taxed at 50 per cent up to the tax breakeven point. The concept of a "tax break-even point" is discusscd at pp. 413.14 infra.

69. The greatest invasions of privacy have involved detection of the man in the house. Parrish v. Civil Service Comm'n, 66 Cal. 2d 260, 425 P.2d 223, 57 Cal. Rptr. 629 (1967).

70. One method for solving these household determination problems is to climinate 
of a household bear an uneasy resemblance to those needed to determine who received gifts from whom if the analysis of the source and amount of funds received by a mother and children is pursued with any vigor. ${ }^{71}$

The acceptability of investigations to determine household membership will depend on the tact and understanding which investigators bring to their work. If they approach it with suspicion rather than as an attempt to resolve an admittedly difficult fact situation, the administration of an NIT will not be a significant improvement over current welfare administration.

\section{Comparison with the Model NIT}

The Model NIT takes a somewhat different approach to the manin-the-house-problem. ${ }^{72}$ Its basic thrust is automatically to exclude a man from a family unit unless he is married to the woman or has fathered her child. Thus a husband is considered part of a wife's household unless there is a legal separation or divorce or an informal separation. If the man had never been married to the woman, he is excluded-assuming they have no children-even if they live together. If the man is the father of the woman's child, domicile with the woman will result in the man's inclusion in the family unit; but if the man's paternity is not established, he is excluded despite domicile with the woman.

the relevance of a split household for NIT purposes. Some progress towards this goal can be obtained by providing equal increments to the minimum allowance per additional member of the family. See also p. 423 infra. Doubts about the real differences in budgetary needs of added members of the household support this approach. See note 55 supra. If it is thought too generous to provide the same allowance per child as per parent, a lesser amount can be provided for each child. Care must be taken, however, that a two-member household does not claim that it consists of two adults, if it only consists of one adult and one child.

Manipulation of allowances per member of the houschold, hovever, will not climinate the motive to split the household when the man earns income since the adjustment of the minimum allowance schedule does not remove incentives to avoid the 50 per cent NIT tax rate on income. Reducing the tax rate to eliminate this incentive would raise the cost of the program by creating a higher break-even point, if the minimum allowances were maintained; and if the break-even point were maintained and the tax rate were reduced, then the minimum allowances would have to be reduced which might
cause them to be inadequate.

Perhaps the incentive to claim a split household would be reduced if there were some service which would be supplied to families that included a man in the houselold and which would not be provided if the man were not part of the houschold. Thus, public housing or federal loans for housing could be made unavailable for apartments or homes over a certain size if the family did not include a man. Of course, this vould not climinate the importance of accurately identifying houscholds; it would only help climinate the incentive to falsify information.

71. See p. 393 supra.

72. MODEL NIT 307-09 (\$ 9). 
These provisions apparently try to eliminate the administrative burden and potential for abuse inherent in investigations concerning a man-in-the-house unless there is objective evidence which establishes some likelihood of a household. The spirit of this proposal is in accord with the objectives indicated above. The question is whether the proposal will be effective in accomplishing these goals.

In the case of a man and woman without children, the approach of the Model NIT will eliminate inquiries about the man-in-the-house unless the man is the husband, a fact which can normally be established with some objectivity. The existence of common law marriages, however, might present difficulty. The Model NIT might, therefore, be more rigorous in the pursuit of its objectives if marriage were only considered when it was evidenced by a document.

Of course, if the man is the husband, delicate inquiries about the man-in-the-house are not eliminated-if there is informal separation the husband is excluded from the household. Since the Model NIT requires different residences for a finding of informal separation, the investigation is similar to the search for a household and could still be a source of abuse. Furthermore, this provision might discourage marriage, a danger acknowledged in the Comment, since the man is included in the household only if he is the husband. There is, of course, a similar danger even if the "household" unit could include a man who was not the husband, since the NIT administrators might find it difficult in practice to avoid a presumption that the man should be included within the household only if he is the husband.

If the woman has a child the Model NIT includes the man in the household only if he is the father and if he is domiciled with the woman. Of course, "domicile" is as difficult to determine as "household." The question is whether limiting this inquiry to cases of paternity significantly restricts the inquiry to cases which can be objectively identified. The name of the father of a child born out of wedlock is not likely to be recorded publicly. Investigations to determine paternity are likely to be as sensitive as inquiries about a household.

On balance, the advantage of limiting inquiry about the man-in-thehouse to cases where he is the husband of the woman or the father of the child seems insignificant. In spite of its difficulties, the concept of the household most accurately expresses the general principle, and specific legislation, short of allowing the man to be excluded in all cases, is not going to eliminate the investigation of sensitive situations.

A household approach also requires determining whether several 
adult members of a family who live together, such as a mother-in-law and her child, are members of a household, whereas the Model NIT does not impose such a requirement. Arrangements involving relatives, however, are not as transitory or as sensitive as arrangements between a man and a woman.

If the household approach suggested in this article is taken, a problem arises when the man is part of the woman's household but does not treat the children as part of the economic unit. The Model NIT has dealt with this situation by providing that children are to be treated as a separate household for NIT purposes if the man in the woman's household owes no duty of support to the children and does not in fact support them. Under the Model NIT, this could only occur in the case of a stepfather since a man not married to the woman cannot be part of her household unless he has fathered her children, in which case he owes a duty of support to the children. The treatment of children as a separate household should be developed further. Whenever the man fails to support the children, even if he is part of an economic unit including the woman, children should receive NIT benefits based on the allowance provided for dependents. However, the treatment of the children as a separate household should not depend, as it does in the Model NIT, upon whether the man has a legal obligation for the children. Therefore, whenever the father, stepfather, or other man who is part of the woman's household fails to provide support, the children should be eligible for NIT benefits. If this approach were adopted and the man were part of the woman's household but not the children's, his income should be taxed at $\mathbf{5 0}$ per cent up to the breakeven point for two adults. The woman's income should be included as part of the resources of the children's household, however, since it is presumably used for their benefit.

\section{Distribution of Benefits}

After developing a definition of income and a minimum allowance schedule, a system for distributing benefits to the beneficiaries must be established. There are several major problems. First, how should declarations of resources and withholding be used to obtain accuracy in the distribution of net benefits? Second, if NIT benefits are excessive, should refunds of overpayments be demanded from beneficiaries? Third, what automatic penalties should be imposed if beneficiaries file declarations which underestimate their NIT tax bases? 
Fourth, what assistance should be given to beneficiaries in filling out their declarations and in computing benefits?

\section{A. Declarations and Withholding}

There are three types of declarations which should be filed by an NIT beneficiary to be eligible to receive benefits. First, the beneficiary should have to declare his name, his address and the members of his household, together with their social security numbers. This is a "declaration of status." Every potential recipient need not file such a declaration. If it is expected that income will exceed the break-even point, an individual who did not expect to end up as a net beneficiary from NIT payments would probably not want to receive benefits. He would thereby avoid the difficulties of having to make income estimates, of being subject to withholding, and of dealing with the NIT administration. Second, the beneficiary must file an income estimate, either initially or periodically during the year, in order to insure that the benefits which he receives bear some relation to his needs, unless withholding from income can accomplish this result. Third, a final declaration must be filed annually to determine whether or not the benefits received during that year have been inadequate or excessive.

In order to determine the rules that should apply to the filing of these declarations, let us begin with a simple example of a family of four in which the father earns $\$ 2,600$ in wages during the year in equal weekly installments of $\$ 50$. We will also assume that the period for determining eligibility is the entire calendar year. Thus low income in one month will not be the basis for higher benefits than would be dictated by annual income. ${ }^{73}$

If the beneficiary is employed prior to the beginning of the calendar year, it would seem appropriate for him to file his declaration of status with his employer in much the same manner as he now files a W-4 form with his employer to tell the employer the number of exemptions to which he is entitled. The employer would then handle the paper work by forwarding the declaration to the government, which would place the employee's family on NIT beneficiary rolls. Since the 50 per cent withholding rate for NIT beneficiaries is well above normal

73. For example, no income during the first half of the year and $\$ 2,600$ during the last half would result in the same $\$ 1,300$ tax and $\$ 700$ bencfits as if the $\$ 2,600$ werc earned in equal weekly installments. The beneficiary would not be entitled to $\$ 1,000$ which is one-half of the yearly minimum allowance, because he had no income during half the year. Determination of benefits on the basis of monthly, not annual, income is discussed at pp. 421-22 infra. 
withholding rates, ${ }^{74}$ the agency administering an NIT would have to make sure that employees have correctly informed employers that they are receiving NIT benefits. Benefits should probably be paid monthly to assist the family with budgeting; less frequent payments simply increase the risk that large lump sum payments will be squandered, leaving the family with no resources, and more frequent payments might be too much of an administrative burden. If the beneficiary were unemployed prior to the beginning of the year, he would have to file his declaration of status directly with the agency administering the NIT.

It does not seem wise to require employees to estimate wage income. The sole purpose of filing declarations of estimated income is to enable an accurate distribution of benefits during the year. Thus, an estimate of $\$ 2,600$ income would reduce net benefits to $\$ 700$ from $\$ 2,000$; i.e., by 50 per cent of $\$ 2,600$. The difficulties of estimating income, however, are considerable and beneficiaries should not have to rely upon estimates if it is not necessary. Subject to certain limitations discussed below, the wages received by an NIT beneficiary can be subject to withholding so that the net NIT benefits received by wage earners are correct. In our hypothetical case, the father can receive the full minimum allowance of $\$ 2,000$ in equal monthly installments and still not receive excess benefits if 50 per cent of his wages are withheld each week. ${ }^{75}$

There are two methods for applying the withholding rate. First, wages would continue to be subject to withholding at the 50 per cent rate until the tax break-even point is reached. ${ }^{70}$ This approach to

74. IRC \$ 3402(a).

75. Fifty-two times $\$ 25$, which is the one-half of the $\$ 50$ weekly salary, would be withheld. This equals $\$ 1,300$, which is one-half of the income received during the year. An alternative procedure whereby the employer reccives the net bencfit from the government and pays it to the employee with his wages is discussed at p. $419 \mathrm{infra}$.

76. The tax break-even point is somewhat higher than the break-even point. In the hypothetical plan, the break-even point is $\$ 4,000$. Consider a family of four with $\$ 4,200$ in wages. Its taxable income is probably $\$ 1,200$ assuming no business or personal deduc. tions and no excludible income under the regular income tax laws. The tax thercon would be $\$ 174$ which is considerably more than 50 per cent of the $\$ 200$ in excess of the break-even point. IRC \& $3(\mathrm{~b})$, table III. Thus, it would be more advantageous for the taxpayer to continue to be taxed at 50 per cent of the excess over $\$ 4,000$ rather than to be taxed as though he were a regular income taxpayer. The rate of withholding would, therefore, continue to be 50 per cent until the regular income tax equaled 50 per cent of the excess over the break-even point. The point at which this equality is reached is referred to as the tax break-even point; for our family of four, it would be $\$ 4,40 S$. The 50 per cent tax rate would, of course, be too high if personal or business deductions reduced gross income below $\$ 4,200$. Therefore, the application of the 50 per cent rate to income between the break-even point and the tax break-cren point could be optional. It is probably too complex, however, to introduce this option into the withholding tables in administering an NIT, although a regular taxpayer can reduce withholding if he 
withholding keeps the taxpayer current on his NIT tax obligation even if he quits work, since the NIT beneficiary's wages are taxed until they reach the break-even point. A similar technique is used under the Social Security Law; the specified percentage continues to be withheld until wages reach $\$ 7,800$ and this withholding stops. ${ }^{77}$

Second, each month's wages could be considered as one-twelfth of the annual wages and be subject to withholding accordingly. This method of withholding is followed under the regular income tax. If, instead, withholding under the regular income tax were kept current so that nothing was withheld until an obligation was due, there would be wide fluctuations in withholding. If the head of a family of four earned $\$ 300$ per month, there would be no withholding until November when his $\$ 3,000$ of deductions for personal exemptions and his minimum standard deduction were used up. In November and December, 14 per cent of his salary would suddenly be withheld and he would take home less per month than he had been accustomed to. To avoid this problem, each month would be treated as a microcosm of the entire year; one-twelfth of the $\$ 3,000$ deductions is allocated each month, and $\$ 50$ per month is subject to the 14 per cent withholding rate. ${ }^{78}$

Which of these two withholding methods, the Social Security or the regular income tax model, should be used under an NIT? It would certainly be much simpler for the employer to use the federal income tax model. Under this model the employer does not have to keep track of total wages paid for the year; instead the employer can determine the amount of withholding required for the relevant pay period by consulting withholding tables. Although it is true that the employer must keep track of total wages paid each employee for Social Security, the amount of tax to be withheld does not vary with the size of the family. Since tax break-even points do vary with family size under an NIT, computations in addition to those required for Social Security would be necessary if withholding for an NIT used the Social Security model.

But if the federal income tax model were used under an NIT, it is likely that some underwithholding might occur. If an NIT bene-

anticipates that his taxable income will be less than gross income under certain circumstances. IRC \& 3402(m).

77. IRC $\$ 3102(a), 3121(a)(1)$.

78. Compare the withholding from annual pay periods, IRC \& 2302(a)(2), table 7(b), with withholding from monthly pay periods, IRC \& 3402(a)(2), table 4(b). IRC \& 3402 (b)(1) incorporates exemptions into the withholding tables for cach pay period. 
ficiary earns wages at a monthly rate which, if maintained for the whole year, would exceed the amount of income subject to the NIT tax rate, then some portion of the monthly income would suffer withholding at less than the NIT tax rate, since the withholding method assumes that income in a later pay period will be subjected to the NIT rates. If the employee stops work before the year is over, ${ }^{79}$ however, underwithholding will occur because the NIT tax rates are regressive.

Eliminating the possibility that underwithholding may occur under an NIT may not be advantageous since the remedy may create an incentive not to work. For if the tax is withheld at a 50 per cent rate until the tax break-even point is reached, more might be withheld during a pay period than is transferred to the beneficiary. ${ }^{\mathrm{s}}$. The head of a poor family will most likely hold down a full or part-time job for a while and then be temporarily out of work, or another member of his family might supplement family income in this pattern. ${ }^{81}$ If an NIT beneficiary is head of a family of four, the basic grant he is entitled to might be $\$ 2,000 ; 82$ if he were offered part-time work or a temporary job paying $\$ 433.33$ per month, his monthly minimum allowance would be one-twelfth of $\$ 2,000$ or $\$ 166.67$, but the amount of withholding at 50 per cent rates would be \$216.67. Less withholding would occur if the federal income tax model were used, although, at

79. For example, if the employee works for six months and carns $\$ 2,600$, only $\$ 1,000$ would be withheld under the NIT if each month werc treated as a microcosm of the entire year. It would be assumed that $\$ 2,000$ of another $\$ 2,600$ earned in the last six months of the year would be subjected to 50 per cent withholding. If the cmplojec stops work at the half year, there would be $\$ 300$ underwithiolding for the jear.

Under the regular income tax the result of stopping work is overwithholding. This results because tax rates are progressive and a portion of income for each pay period is treated as though it were subject to the graduated rates appropriate if the rate of carn. ing income persisted. However, stopping work reduces annual income so that the ap. plicable tax rates are below the graduated withholding rates. The simplest example is the single taxpayer earning $\$ 900$ in one month and then not viorking after Uat. He gets the benefit of only one-twelfth of his $\$ 900$ deduction for a personal exemption and minimum standard deduction and suffers withholding not merely at the 14 per cent bottom rate, but at graduated rates. See tables in IRC $\$ 3402(a)$.

A different procedure is followed in the United Kingdom where pay periods are cumulated and lower withholding rates and even refunds are made if later pay periods indicate that there was excess withholding during earlier periods; sce Murray. IWith. holding and Pay as You Earn: $A$ Contrast in British and American Methods of Tax Collection, 1962 Britrsh TAX Rev. 173, 176.

80. In this example the NIT beneficiary has declared himself cligible for NIT benefits because he does not expect to maintain this income level for the jear. The amount withheld during the prosperous months would not result in cxcessive with. holding if the entire year's income is considered; it will simply look like a large amount to withhold to the employee.

81. C. GREEN, supra note 5, at 4, cites Social Security data which indicate that in 1963, 22 per cent of poor families had a head of the family who worked at a full time job less than 50 weeks during the year and 14 per cent who worked at part-time jobs.

82. See note 3 supra. 
this monthly income, more would be withheld than the beneficiary would receive in benefits; only one-twelfth of the tax break-even point $(\$ 4,408)$ would have suffered withholding at the 50 per cent rate, which amounts to $\$ 183.67$. The regular withholding rate of 14 per cent, not 50 per cent, would apply to the excess of monthly income over $\$ 367.33$. Total withholding per month would be $\$ 192.91$, which is more than the $\$ 166.67$ in benefits but less than 50 per cent of earnings. ${ }^{83}$

This concern with disincentives to work will not be shared by those who place a great deal of faith in provisions, similar to the recent amendments to the Social Security law, which provide for a reduction in benefits if a beneficiary refuses work without good cause. This approach to encouraging work, however, is at variance with the theme of the NIT. The imposition of penalties for not working requires administrative decisions as to whether the unemployment was justified. Instead, an NIT seeks to encourage beneficiaries to work by providing automatic incentives in the form of reduced tax rates on earnings (as compared with the 100 per cent tax rate imposed by welfare laws). ${ }^{84}$

The other withholding problem under an NIT is overwithholding. If the father earns $\$ 2,600$ from one employer and either he or his wife earns $\$ 2,600$ from another, $\$ 2,600$ would be withheld if both declare themselves NIT beneficiaries and suffer withholding at a 50 per cent rate. The overwithholding problem may be exaggerated. First, it is more serious if there is a low break-even point such as $\$ 2,500$ since overwithholding is more burdensome at lower income levels. Second, it does not arise if total family income is not greater than the tax breakeven point. Third, the problem can be avoided by anticipating that

83. 14 per cent of $\$ 66$, which is the excess of $\$ 433.33$ over $\$ 367.33$, is $\$ 9.24$. This amount, when added to $\$ 183.67$, equals $\$ 192.91$.

84. The new Social Security Law also provides carrots by disregarding the first $\$ 30$ of earnings per month and one-third of amounts over $\$ 30$ in determining the resources of an employed member of the family; there is an added proviso, however, that the zero per cent tax rate on the first $\$ 30$ and the $66-2 / 3$ per cent tax rate on income over $\$ 30$ is available only if the beneficiary does not, without good cause, quit work or reduce earnings. Soc. Sec. Act, 42 U.S.C. \$§ 402(a)(19), 630.44 (1964), as amended P.L. 90.248, $\S \S 204$ (b) \& $204($ a), 81 Stat. 890-92 \& $884-90$ (1967), provides for the creation of programs to integrate beneficiaries into the work force. Soc. Scc. Act, 42 U.S.C. \$ 602(a)(19)(I) (1964), as amended P.L. 90-248, § 204(b), 81 Stat. 891 (1967), mandates that the unjustified failure to participate in these programs will result in the refusal to consider that in. dividual's needs in calculating benefits for the family. See Comment, Compulsory Work for Welfare Recipients under the Social Security Amendments of 1967, 4 Colum. J. of LAw \& Soc. Prob. 197 (1968). Soc. Sec. Act, 42 U.S.C. \$ 607(b) (1964), as amended P.L. $90-248$, § 203(a), 81 Stat. 882-83 (1967), requires that a program to assist families with unemployed fathers, if adopted by a state, include only families whose father has worked and did not leave work without good cause. Soc. Sec. Act, 42 U.S.C. $\S 602(a)(8)(A)(i i)$ (1964), as amended P.L. 90-248, § 202(b), 81 Stat. 881 (1967), provides for reduced rates on a beneficiary's earnings under certain circumstances. 
income will exceed the tax break-even point before the year begins and not declaring for NIT benefits. Fourth, it can be minimized by opting out of the NIT program when excessive withholding is anticipated during the year.

Furthermore, withholding according to the federal income tax model will not remedy the overwithholding problem. $\$ 2,600$ will still be withheld if the two wage earners each earn $\$ 2,600$ in twelve equal monthly installments. The reduced withholding rate under the federal income tax model ${ }^{85}$ helps to prevent overwithholding only if the wage rate for a pay period is such that wages would exceed the tax break-even point if continued all year. A more appropriate method to avoid overwithholding in this case would be to permit only one employer to withhold at 50 per cent rates. If the wife is not the prime earner in the family, perhaps her income should be subject only to regular withholding rates rather than the 50 per cent rate. In most cases, the family's judgment as to who is the prime earner should be accepted. But if the children are treated as a separate NIT household when the man supports only the woman, ${ }^{80}$ the woman should be treated as the prime earner of the children's household for withholding purposes. If the prime earner has two or more employers, however, it might be difficult for NIT administrators to identify a prime source of employment, and if the head of the household has discretion to identify the prime source, he may abuse it. Therefore, all employers of a prime earner should withhold at 50 per cent rates.

All things considered, it does seem best to withhold from prime earners in a household by using the federal income tax withholding methods under an NIT. The danger that work disincentives and inconvenience to employers will be created by the Social Security withholding method outweighs the withholding problems that the federal income tax withholding method entails. And although beneficiaries may not receive the correct amount of benefits because each month's wages are considered one-twelfth of the year's wages under the federal income tax withholding method, having each beneficiary estimate his annual income would probably lead to an even more inaccurate distribution of benefits because of the problems the poor face in accurately forecasting annual income.

It has been assumed thus far that the declaration of status has been filed prior to the beginning of the year. What happens if it is filed 
during the year? If on July 1 , the head of the household learns that he will stop receiving salary or the beneficiary wakes up to his rights under the law, each should be allowed to file a declaration of status to receive benefits for the remainder of the year. The declaration would indicate the wages received by the family prior to the date of filing. The NIT administration would then subtract one-half of the wages received from the total benefits to which the family would be entitled and add back any withholding taxes on such wages. To enable the NIT administration to obtain this information, employers would have to give employees wage and withholding information upon request.

While withholding of the entire NIT tax by the employer and payment of NIT benefits by the government might be the best way to obtain accurate payments of net benefits to beneficiaries, an alternative approach is to have the employer pay the correct net amount to the employee. Under this system the employer would inform the NIT administration of the wage rate paid to the employee who has filed a declaration of status. The NIT administrators would then pay the employer the amount of net benefits to which the employer is entitled. Thus, if the employee earned $\$ 100$ per month, the monthly minimum benefit of $\$ 166.67$ would be reduced by 50 per cent of the salary and sent to the employer, who would pay the employee his salary plus his NIT benefit- $\$ 216.67$ in all. This method of paying the employee may make him feel less like he is on welfare and, by omitting from his pay check an explicit 50 per cent withholding item, encourage work.

This payment procedure, however, creates several difficulties which make it questionable. If the employee's wages increase or decline, the employer must inform the NIT administration and a new computation of net benefits must be made. If the employee loses his job, the administration must be notified and the method and amount of payment adjusted. If a second member of the family begins work and his or her earnings are considered household resources in determining the payment of net benefits, this information must be reported to the administration in order to adjust the net benefits paid monthly. This approach for distributing NIT benefits, as compared with the withholding method, is more burdensome on employers, who must be in more frequent contact with the NIT administrators, and on the NIT administration which must recompute net benefits with every change of wage or employment status. Under this approach beneficiaries might also be subject to the additional burden of keeping the NIT administration informed about the earnings of other members of the family, if such earnings are relevant. The major defect of this pro- 
cedure, however, is that it substitutes periodic reporting and computations for an annual reporting and automatic withholding system. ${ }^{87}$ This procedure would work well only if the poor held steady jobs with steady incomes.

Matters become more complicated when non-wage-earners are considered. If public assistance, private charity and social insurance are included in the tax base, the best approach would be to treat the disburser of such benefits like an employer and require withholding. Should the 50 per cent rate be applied to such payments until the break-even point is reached or should it be applied as though each payment period were a microcosm of the entire year? Because work disincentives will not be created, whatever amount is withheld, and because the payors, at least in the case of Social Security, utilize com. puters to disburse benefits, the objections to the Social Security method of withholding which were persuasive in the case of wages do not control here. Therefore, the 50 per cent tax rate would be applied to the payments until $\$ 4,000$ (the break-even point) were disbursed. And because public assistance and private charity are not likely to be offered if they would, together with other income, provide the family with more income than $\$ 4,000$, there is little reason to worry about the problem of overwithholding. Social Security and wages combined might sometimes exceed the break-even point, since individuals can earn up to $\$ 1,680$ per year without loss of Social Security benefits and the amount of benefits received is based on prior earnings, not on the difference between current income and the poverty line. ${ }^{88}$ Since social Security is steady income and Social Security beneficiaries who work often figure their total income carefully to avoid loss of benefits, Social Security recipients will probably be able to anticipate excessive withholding and withdraw from the NIT program to avoid it.

If it is difficult to withhold taxes from income, as in the case of business or farm income, how frequently should NIT beneficiaries file income estimates? The government could require only an initial estimate and determine net benefits accordingly. Or the government might make full NIT benefit payments to those who have opted into the NIT plan and then require them to file quarterly declarations of estimated annual income on which they would make payments of $\mathbf{5 0}$ per cent in order to insure that the correct amount of net benefits are received. ${ }^{89}$

87. See p. 420 infra.

88. See J. Pechman, H. Aaron \& M. Taussig, Soclal Securitr. Perspectives for ReFORM 78-118 (1968).

89. For example, if monthly payments were recived and an estimate was filed each 
There do not seem to be any advantages in requiring quarterly declarations of estimated income with a payment rather than initial declarations on the basis of which future NIT benefits would be reduced. First, the quarterly declarations do not eliminate the need for an initial declaration of status. Therefore, the burden of coming forward to deal with the bureaucracy must be suffered in any event. Second, it is not likely that low income beneficiaries will budget so that they will have funds with which to make the quarterly payment. Third, poor people are unlikely to be able or be willing to keep adequate records and cannot be expected to make estimates of income at quarterly periods that are much more reliable than initial estimates. Thus, individuals receiving income which cannot be subjected to withholding, such as farm and business income, should be required to file initial estimates of income at the same time that they file their declaration of status.

If the beneficiary discovers during the year that his annual income is greater than his estimate, he could inform the NIT administration of the increase. Benefits might either be reduced or stopped completely. Thus, if the beneficiary initially estimated $\$ 1,600$ of business income, he would have been receiving $\$ 100$ of NIT benefits per month. ${ }^{00}$ If his new estimate is $\$ 3,200$, total benefits would be $\$ 400$ and if five months had already expired there would already be an overpayment; benefits would therefore cease. ${ }^{21}$

A beneficiary could also lower his estimate; this is the equivalent of filing for benefits in the middle of the year. The beneficiaries would then either receive increased monthly NIT payments or, perhaps, a lump sum payment. For example, an initial estimate of $\$ 1,600$ would yield $\$ 1,200$ of benefits in $\$ 100$ monthly installments. If a revised estimate of $\$ 1,000$ were filed after four months, the beneficiary would be entitled to receive $\$ 1,500$ less the $\$ 400$ already received. No attempt would be made to identify business income received to date, as in the case of wage income, ${ }^{22}$ since bookkeeping and accounting problems make that too formidable a job for the poor. Receiving a lump sum payment is optional since cash flow from a business does not necessarily

quarter stating that income for the year would be $\$ 2,000$, the income for the quarter would be $\$ 500$ and 50 per cent, i.e., $\$ 250$, would be paid to the Government.

90 . One-half of $\$ 1,600$ is $\$ 800$ which would reduce the $\$ 2,000$ minimum allowance to $\$ 1,200$ per year, i.e., $\$ 100$ per month.

91. The repayment would be in accordance with the rules discussed at pp. 422.28 infra.

92. See pp. 418-19 supra, discussing back payments to wage-earners based on prior income during the year. 
fall into neat periods and the beneficiary might prefer regular monthly income.

Once a family entered an NIT program, it would continue in it until it decided to withdraw. Estimates for the prior year would continue to apply in determining the current year's distributions. After the year was completed, final declarations of income received during the prior year would be filed and overwithholding or underwithholding would be determined. It seems appropriate to require that the final declaration be filed by April 15, as in the case of the income tax and Social Security declarations, since this is the date when filing is "in the air." An estimate of annual income for the current year, other than income on which withholding is required such as wages, private charity, public assistance, or social insurance, would be declared on the final declaration form. This information would be used to recompute the payment of NIT benefits during the current year if a change was called for by the estimate.

It would seem administratively undesirable to require beneficiaries to report past income more frequently than on an annual basis, because employers would have to compute income just as frequently to provide employees with this information; it is enough of an added burden to require employers to compute wages paid up to the time when the employee leaves his employ, if requested to do so, as suggested in connection with filing for benefits in the middle of the year. Another objection to reporting income more than once a year is that NIT auditors would be able to check a smaller percentage of each batch of returns than if they were to concentrate on a larger percentage of returns filed annually. Better compliance might be obtained if the larger percentage sample were chosen.

Prior discussion has assumed that the calendar year is the basis for determining eligibility. Suppose, however, that a household with $\$ 5,000$ annual income receives no income in one month. Should the family be entitled to receive and keep one-twelfth of the $\$ 2,000$ minimum allowance in that month or should the calendar year be the basis for determining eligibility for NIT benefits? It is unlikely that the employee would have accurate information about his monthly income. And employers would bear a considerable additional burden if they were required to record information about monthly wages. It is true that the Social Security Act requires reports of monthly income on the annual return. But the Social Security Act requires the employee to specify only whether the $\$ 140$ per month exemption level is ex- 
ceeded. ${ }^{93}$ Under an NIT, precise information about the beneficinries' monthly earnings would be required in order to accurately compute the benefits payable. And since an NIT would cover more beneficiaries than Social Security, the number of cases where employers and beneficiaries would be asked to supply monthly income information would far exceed those required to do so under the Social Security Act. Thus it appears that accurate information about monthly income would be very difficult to obtain; eligibility should be based on annual income. $^{94}$

\section{B. Comparison with the Model NIT}

The Model NIT proposes that a family receive semimonthly payments unless it prefers to wait until the end of the year and receive benefits based on the prior year's income.95 The semimonthly payments, however, are reduced ratably by 50 per cent of a quarterly estimate of annual income. The estimate has two components. First, an extrapolation based on income for the prior quarter or for those quarters of the year in question preceding the date of the estimate. Second, a statement in which it is estimated whether income for the year will vary by ten per cent from this extrapolation based on past income; in that case, the administrator shall vary the benefits due the beneficiaries for the current quarter accordingly. This approach requires poor people to file returns for periods for which employers are not normally supplying information and to make quarterly estimates of future income. Both these problems suggest that it would be better to require withholding in the case of wages and annual estimates for income on which withholding is impractical.

The comments to the Model NIT suggest that withholding for NIT purposes introduces a second withholding system which is burden-

93. Forms SSA-I (line 12(c)) and SSA-777 (line 1(b)).

94. Since annual eligibility periods could be considered the equivalent of monthly periods averaged over the year, why not average over periods longer than a year? The substantive question is to decide over what period to determine whether poverty exists and, therefore, welfare benefits are appropriate. Should a family with income above poverty levels in one year whose income declines or whose annual income is below poverty levels but increases in the next year receive NIT benefits? No attempt is madc to resolve this question here. The administrative considerations favor an annual eligibllity period since it coincides with the reporting period. Averaging over more than one ycar would require maintaining information from several reporting periods and adding to. gether income of more than one period. Tobin, Pechman \&e Mieszokowski 20, suggest that the rich man whose income fluctuates would be denied NIT benefits in most cases by the tax on wealth, see note 45 supra, and by a further proviso that the privilege of averaging income be denied for income tax purposes if NIT benefits were received in prior years. IRC $\$ \S 1301.04$.

95. MODEL NIT 303-06 (\$ 8). 
some to the government and to employers. However, the burden on employers is kept to a minimum. The NIT withholding tables are integrated with the regular withholding tables. It is true that two sets of withholding tables are necessary, one for NIT beneficiaries and one for other employees. But that does not seem too burdensome. The fact that the government pays out large sums with one hand while taking back much of the money on the other must be balanced against the burden on beneficiaries and the government of quarterly returns.

There is one problem in constructing withholding tables which has not been mentioned. We are accustomed under the regular income tax to equal exemptions regardless of the make-up of the family. Under the NIT, there is a variation in benefits for each additional member of the household depending upon whether the member is an adult or child. For example, if benefits are $\$ 800$ per adult and $\$ 600$ per child, four member households will not always receive equal benefits. The problem can be solved mathematically. An adult is worth " 4 " and a child " 3 ." The withholding tables for NIT beneficiaries would be constructed for all possible combinations. For example, " 4 " ( 1 adult), " 7 " ( 1 adult, 1 child), " 8 " ( 2 adults), etc. This is obviously cumbersome and is an added argument favoring equal benefits for each member of the unit.90

\section{Repayment of Excess Benefits}

An overpayment can occur in several ways. First, the tax on a working wife or child might not have been withheld at a 50 per cent rate. ${ }^{97}$ Second, a beneficiary might receive a large amount of income in one pay period subject to the 50 per cent rate and no income in another period. ${ }^{98}$ Third, income estimates might be too low..$^{93}$ Fourth, the employer might fail to withhold at the 50 per cent rate because he was not told that the employee was an NIT beneficiary and because the NIT administration failed to notify the employer. ${ }^{100}$ Fifth, the beneficiary might have claimed too many exemptions.

Should beneficiaries be required to reimburse the government for the overpayments received? The Social Security Administration forgives repayment if an individual is poor at the time when an overpay-

96. See pp. 408-09 supra.

97. See p. 417 supra.

98. See pp. 415-16 supra.

99. See p. 420 supra.

100. See pp. 412-13 supra. 
ment is determined. ${ }^{101} \mathrm{~A}$ similar rule should apply in the case of NIT benefits. $^{102}$ Of course, this means that a withholding system which allows a beneficiary to get more than he is ultimately entitled to receive will sometimes result in the permanent retention of excess benefits. Perhaps repayment should also be postponed, or even forgiven, if the individual's income is just above the poverty line, since the repayment appears as an increase in marginal rates and might discourage work. Only individuals who suddenly become well-off should be required to make lump sum payments. For the others, repayments could be made in installments if not completely forgiven. ${ }^{103}$

Having the obligation to reimburse the government for overpayments which vary in this manner gives the NIT administrator considerable discretion. When an overpayment is detected, a juclgment must be made of the expected income and resources of the beneficiary in the year to come in order to decide whether to require a repayment or to spread the repayments out over a period of time. But since this is not a discretion to determine eligibility, the potential for abuses should not be as worrisome as when eligibility was an issue.

A more difficult question is what to do in the case of a beneficiary whose income rises above the level at which he is considered able to make repayments after the overpayment is determined. Many welfare programs still require repayment. ${ }^{104}$ The administrative problem is that it is extremely difficult to devise a "tickler" system which will call attention to those beneficiaries who later acquire resources. Perhaps the only feasible method of doing this is to program the computers that handle income tax returns to disclose former NIT beneficiaries who report income in excess of the figure at which it is considered appropriate for him to make repayment of prior overpayments. The increased cost of administering such a repayment program combined with a more generous view of welfare than is implicit in many state programs will probably lead to a forgiveness of any repayment obligation if the beneficiary is poor when the overpayment is discovered, despite a later acquisition of resources.

101. 20 C.F.R. $\S 404.506$ \& 404.508 (1968); cf. Soc. Sec. Act, 42 U.S.C. $\S$ 404(b) (1964). 102. The problem of the poor refunding overpayments is related to the substantive issue of income-averaging when income declines. In both cases it must be decided whether earlier resources should be used to reduce welfare benefits for a later period when income is below poverty levels.

103. Repayments by those above the poverty level are similar to the problem of income-averaging under an NIT when income rises after a period of low income. In both cases a requirement of repayment might discourage work.

104. See Graham, Public Assistance: The Right to Receive; The Obligation to Repay, 43 N.Y.U.L. REV. 451, 475-96 (1968). 
Whenever the overpayment is caused by the "fault" of the beneficiary, repayment should be required whenever adequate resources are obtained. This rule is followed by the Social Security Administration. ${ }^{105}$ Fault is not always easy to identify, especially in the case of low income beneficiaries who are not familiar with forms and bureaucracy. Examples of fault might include the continuous underdeclaration of the income of a successful business and the claiming of nonexistent members of the households.

The Model NIT allows deduction of excess benefits paid during the year from future benefits up to 0.5 per cent of total annual benefits, ${ }^{100}$ although recapture of prior overpayments is, apparently, discretionary. The preceding discussion dealt primarily with criteria for exercising that discretion. The 0.5 per cent limit on recapture in the Mlodel NIT focuses on the amount of subsequent NIT benefits. Thus more is repaid the poorer the beneficiary becomes, whereas recapture should depend on outside income and wealth of the benficiary in the later years.

\section{Automatic Penalties for Underdeclaration}

It does not seem unreasonable to impose an automatic penalty on overpayments for the use of the money if there has been an underdeclaration of income, even if no repayment is required. And it seems appropriate to use the six per cent penalty imposed by the regular income tax for underestimation of income. ${ }^{107}$ What is a realistic standard of accuracy to apply to poor people receiving benefits? ${ }^{108}$ Certainly no penalty should be imposed if the initial declaration of income for the current year equals the income received in the prior year. ${ }^{109}$ If the current income estimate is lower than business income of the prior year, one solution might be to impose a penalty only if the actual income realized was more than twice the amount initially declared, except that no penalty would be imposed if the income actually received does not exceed $\$ 2,000$. This solution is based on the assumption that poor people cannot reasonably be expected to estimate their income any more accurately than 50 per cent of the

105. Soc. Sec. Act, 42 U.S.C. \& 404(b) (1964); 20 C.F.R. Reg. 4, $\S \S 404.506 .07$, 401.510-11 (1968).

106. MODEL NIT $306(\S 8(j))$.

107. IRC \& 6654(a).

108. Under the regular income tax considerable leeway is given to the taxpayer in estimating his income. IRC $\S 6654$ (d).

109. IRC $\S 6654(\mathrm{~d})(1)(\mathrm{B})$. 
realized amount, and that taxpayers with income of $\$ 2,000$ or less from business or farm sources cannot even be kept to this standard. In cases of extreme hardship, it might be appropriate to allow the penalty to be paid over a period of time. It is difficult to imagine, however, that the penalty would be considered excessive. If business income for the first year was $\$ 2,000$, the estimate for the second year was $\$ 1,500$, and actual business income in the second year was $\$ 2,500$, the extra $\$ 1,000$ of income results in an overpayment of $\$ 500,6$ percent of which is $\$ 30$. Furthermore, a penalty would rarely be required since most of the income of NIT beneficiaries will be in the form of wages, private charity, public assistance, or social insurance, which would have suffered withholding and need not be estimated.

\section{E. Computation of Benefits and Completion of Tax Form}

Although considerable emphasis is placed on self-assessment and voluntary compliance under the regular income tax, ${ }^{110}$ low income taxpayers can realize these goals only with difficulty. The Internal Revenue Service recognizes the problems a low income taxpayer faces in computing his tax by providing simple tax tables for those with incomes of $\$ 5,000$ or less ${ }^{111}$ and by giving him the option of having the IRS compute the tax and send him a bill, rather than requiring him to perform the much heralded job of assessing himself. ${ }^{112}$ The IRS also provides a considerable amount of personal assistance to low income taxpayers who come to their local offices to enable them to complete their returns accurately. An NIT will deal with large numbers of poor who are even less capable than low income taxpayers in understanding instructions, making computations, or dealing with forms.

NIT beneficiaries will need particular assistance from local offices to answer a number of difficult and confusing questions especially relevant to an NIT. Beneficiaries will want to know, for example, whether to participate in or withdraw from the system at the beginning of the year or during the year, ${ }^{113}$ how to determine their income under an

110. Self-assessment means that taxpayers compute the tax which they owe and send it to the government. IRC \& 6151(a). Voluntary compliance refers to the fact that information is gathered in most cases from the taxpayer's own declaration, rather than through enforcement techniques such as a summons; most information is obtained from returns filed by taxpayers pursuant to IRC $\S$ 6011(a) rather than pursuant to a stut1. mons under IRC \$ 7602 .

111. IRC \& 3 .

112. IRC $\S \S 6014,6151(\mathrm{~b})(1)$.

113. See p. 417 supra. 
NIT because of the different rules concerning inclusion and exclusion of items and the aggregation of family income, ${ }^{114}$ and whether they should exercise the option to be taxed at 50 per cent rates over the break-even point until their income reaches the tax break-even point. ${ }^{115}$

\section{Who Will Administer the NIT?}

What agency is best suited to administer the NIT or should a new agency be created? The prime consideration in deciding this question should be that the NIT is a welfare program, not a revenue measure.

Should this premise exclude the Internal Revenue Service as an administrator? The IRS labors mightily to appear helpful to taxpayers and to avoid antagonizing the public. Although it must deal with sensitive elements of the population as part of its function, it would not be wise to require the IRS to deal extensively with the poor unless necessary. The public's image of the IRS would certainly be affected if it appeared to be badgering poor people. And the poor might be less reluctant to comply with the regular income tax when they joined the ranks of regular taxpayers in the future. Still an NIT beneficiary might believe that the IRS would deal more favorably with them than do the current administrators of welfare laws. The IRS certainly tends to be less overbearing than welfare administrators. It is less likely to explore every nook and cranny of a taxpayer's history and more likely to focus only on significant issues. This is based on the IRS's intensive effort to attain professional audit standards, an efficient allocation of limited resources, and a good public image. Professionalism, managerial planning, and public relations seem to be coming to the administration of welfare laws, if at all, very belatedly. But if welfare administrators could adopt the professionalism and modern management techniques of the IRS and at the same time be understanding of the problems faced by beneficiaries, it would be better if welfareoriented administrators enforced the NIT. IRS agents, despite attempts at understanding, are trained to look for omissions by individuals, and for failures to comply, rather than for excuses for noncomplinnce. The IRS should, however, handle mechanical functions not involving taxpayer contact or investigation. Declarations of status and income should be filed with the IRS by the beneficiaries and their employers, and

114. See pp. 389-403 supra.

115. See pp. 413-14 supra. 
benefit computations should be handled by computers at the IRS computing center, if this would be economical.

Is there an agency, then, which distributes benefits but which does not have the shortcomings of the IRS or of the current administrators of public assistance?

The Social Security Administration can probably satisfy these requirements. ${ }^{116}$ It must deal with the poor, ${ }^{117}$ and its staff is accustomed to assisting aged individuals who often are unable to deal with forms, numbers, and bureaucracies. The Social Security Administration must also decide whether and in what manner overpayments should be repaid and determine whether the beneficiary is at fault in causing the overpayment. ${ }^{118}$ In order to perform these functions, its offices are much more decentralized than IRS district offices; many are located in urban ghetto areas. ${ }^{119}$ Under current practice, claims representatives in the Social Security district offices both assist applicants and determine whether the beneficiary is able to repay an overpayment. This arrangement seems useful; those deciding whether overpayments should be returned should also have experience in assisting individual beneficiaries.

The Social Security Administration, however, does lack significant and detailed experience in auditing and investigating income records. ${ }^{120}$ Under current practice, claims representatives rarely initiate investigations of a beneficiary's income of their own volition. Generally an investigation occurs only when an initial declaration is filed.121 And annual returns of income are generally audited only upon the request of a regional payment center and then only when initial estimates and

116. Viles, The Social Security Administration Versus the Lawyers-And Poor Pcople Too, 39 Miss. L.J. 371, 391-405 (1968), notes the Social Security Administration's record of excellence in dealing with beneficiaries, but still finds it somewhat middlc-class oriented.

117 . In 1961, 62.9 per cent of Social Security benefits were received by those who were poor before receiving their Social Security; C. GREEN, supra note 5, at 20.

118. Soc. Sec. Act, 42 U.S.C. § 404(b) (1964).

119. 33 Fed. Reg. $5837-43$ (1968).

120. It is true that wages and business and farm income will reduce benefits if they excecd $\$ 1,680$ per year and $\$ 140$ in any one month. Soc. Sec. Act, 42 U.S.C. \& $401(\mathrm{~b})$ (1964). The NIT tax base, however, will include many other kinds of income and there will probably be no exemption. The NIT will also require determining the incomc of the entire family and membership in the household. At present, income of other members of the family besides the beneficiary are irrelevant for Social Security purposes and marriage is the criterion for determining whether benefits cease, without regard to the marriage is the criterion for determining whether bence of a household. Children's benefits, 42 U.S.C. $\$ 402(\mathrm{~d})(1)(B)(1964)$, and widow's benefits, 42 U.S.C. $\S 402(\mathrm{e})(\mathrm{I})(\mathrm{A})$ (1964), cease on remarriage.

121. For example, if a businessman files for benefits claiming that his wife now owns the business, an investigation to see if he has really divested himself of the income is often warranted. See, e.g., Dunlap v. Ribicoff, 207 F. Supp. 511 (D. Kan. 1962). 
final declarations by the beneficiary do not match or the beneficiary's and the employer's returns do not match. Little effort seems directed at developing audit criteria for checking income or checking samples of beneficiaries to determine if income is accurately reported. Most audit programs involve verifying events which determine eligibility, such as a disability, ${ }^{122}$ rather than income of the beneficiary. This auditing and investigating deficiency would have to be eliminated before the Social Security Administrator could effectively administer an NIT.

A difficult administrative problem would be coordinating the auditing activities of the Social Security Administration with the IRS when an individual appears to be on the borderline of the NIT and regular income tax or an individual has filed for NIT benefits but his income exceeds the break-even point. The best approach would require the Social Security Administration to audit the records of any individuals who have filed for NIT benefits. If the Social Security Administration decides that the case might involve payment of the regular tax and would probably involve complex auditing problems, the Internal Revenue Service would be notified and would enter the case if it considered it appropriate. The IRS has an interest in insuring that the Social Security Administration exercises its discretion to notify the IRS in a satisfactory manner. This interest can be protected by permitting the IRS to select and review a sample of NIT returns to determine if the procedures and the criteria for notifying the IRS are adequate. Presumably the IRS would welcome being relieved of the burden of dealing with small income taxpayers whom it pursues more out of a duty to enforce the income tax laws equitably than a conviction that it is producing revenue.

The Model NIT suggests that a new agency in the Treasury administer the NIT. ${ }^{123}$ It seems preferable, however, to build on an existing administrative base if the right one can be found.

There is also a suggestion in the Comment that the NIT and current proposals to reform public assistance are "not so much alternative ways of dealing with poverty as they are alternative ways of dealing with Congress." The suggestion is that reformed welfare programs will be "strikingly similar" to an NIT.

There are several steps which could be taken to make welfare approach an NIT. It is possible to require public assistance programs to

122. Apparently, most litigation which emerges from the Social Sceurity Administration concerns disability. See Viles, supra note 116, at 390.91.

123. MODEL NIT 335-36 (\$ 20). 
use declarations of resources which would be subject to audit on a sample basis and on the basis of rational audit criteria. ${ }^{124}$ Congress could also move towards broadening categories by making compulsory the eligibility of households with a father, or, more broadly, by eliminating all categories. And adequate minimums could be effectively mandated by sufficient federal funding and by requiring state participation up to the minimum level of required benefits in order for states to receive any federal funds; political pressure to join the program would then be difficult to resist. ${ }^{125}$

However, even if a public assistance program with all the reforms noted above were adpoted, a major difference from an NIT would be that state administrators would remain in control. A nagging suspicion persists that the atmosphere of mistrust and dependence which has permeated public assistance programs would continue unless a different administration were put in charge.

\section{Conclusion}

The discussion of the administration of a negative income tax began with an admonition not to obscure its character as a welfare program rather than a tax. In conclusion, it may be wise to reverse positions and urge that, at least in one respect, the NIT be analogized to the regular income tax.

When the income tax was in its infancy, no objection was more

124. State experimentation with declarations is described in Comment, Eligibility Determinations in Public Assistance: Selected Problems and Proposals for Reform in Pennsylvania, 115 U. PA. L. REv. 1307, 1339.45 (1967); proposed regulations requiring a declaration system in all states appear in $33 \mathrm{Fed}$. Reg. 17189 (1968). In their final form, these regulations require only testing of a "simplified method" of needs and resources. They reflect a preoccupation with inaccurate declarations by cstablishing lack of clarity as an audit criterion and by authorizing a fraud warning on the form. 34 Fed. Reg. $1144-46$ (1969).

125. Congress does not secm disposed towards these reforms. The Report of the Advisory Council on Public Welfare in June 1966 recommended many changes in public assistance, among which were the provision of an adequate nation-widc floor on bencfits based on cost of living in each state and the provision of help to all the poor without regard to categories. See Having the Power, We Have the Duty, 4 WELFARE IN REviEw (Dec. 1966) at 1 . An adequate floor was mandated by the Administration's 1967 pro. posals, H.R. 5710, 90th Cong., Ist Sess. $\$ 202$ (1967), but categorics were retained. The bill which emerged from the House Ways and Means Committee dropped requirements for a floor on benefits. H.R. 12080, 90th Cong., 1st Sess. (1967). The floor was not returned to the bill by the Senate. However, the Senate did add a requirement that states must include in their programs of aid to families with dependent children those families in need due to unemployment of the father. 189 CoNG. REc. 16817-20 (1967). Even this modest attempt to expand categories was eliminated in conference. The history of the Social Security Amendmentts of 1967 appears in 6 WELFARE IN REviEw (May-Junc 1968) at 1 . 
vigorously put forth than that it would be inquisitorial. ${ }^{120}$ Professor Seligman considered that withholding was the only solution for a democratic society. ${ }^{12 \pi} \mathrm{He}$ believed that inquisitorial techniques for accurately determining the taxpayer's income were suitable for Germany, but not for the United States; besides, the strain on the administration caused by trying to make such accurate determinations would be too great. ${ }^{128}$ These objections are probably responsible for the much publicized emphasis on self-assessment and taxpayer assistance under the regular income tax and for the speedy adoption of withholding from wages once it became a mass tax.

While we have not been willing to accept an inquisitional income tax, we have nevertheless acquiesced in an inquisitorial welfare system. Preoccupation with the possibility of fraud and overpayments has overshadowed the importance of providing benefits and services to welfare beneficiaries. The proposals in this article do not eliminate problems of overpayment any more than the regular income tax can eliminate underpayments. But a double standard which treats taxpayers and welfare beneficiaries differently is no longer tolerable, and it is in that spirit that the problems of administering a negative income tax program have been discussed.

126. R. Paul, Taxation In the United States 25, 33, 39 (1954).

127. E. Seligman, The INcome Tax; A Study of the History, Tueory, ANd Prac TICE OF INCOME TAXATION AT HOME AND ABROAD 659-60 (1911).

128. Id. 


\section{The Yale Law Journal}

Volume 78, Number 3, January 1969

Editor-in-Chief

Executive Editor

Article \& Book

Review Editors

Managing Editor

Note \& Comment

Editors

Projects Editor

Projects Manager

Publication Editor
JOHN TOWNSEND RICH

RICHARD COTTON

GEOFFrEy DRURY

EDWARD L. STrohbehN, JR.

JoHN F. DIENELT

Alexander Morgan Capron

W. JOHN GLANCY

DEan Heller

BARRY E. CARTER

RICHARD E. AYres

Michael D. Barone
Judith C. AREEN

DEAN D. Aulick

KENNETH C. BASS III

ALLEN R. BENTLEY

JAMES F. Blumstein

RAYMOND P. BOULANGER

JOHN E. BRYSON

JEFFREY A. BURT

WilliaM A. Butler

Charles B. Cannon

Clifford R. Dammers

JOHN F. DAUM

Richard D. DiaMrond

WiLliam Drayton, JR.

STEPHEN S. DunhaM

Michael G. EgGer

MAX FACTOR III

HAMILTON P. FoX III

Paul R. Friedman

Business Secretaries
JOHN J. GEAREN

Paul D. Gewirtz

Peter J. Gregora

Eleanor S. Glass

JOHN P. GODICH

STEPHEN HOCHIBERG

GARY N. JacoBs

MICHAEL I. JEFFERY

WILliam H. JefFress, JR.

William E. Kane

ALAN D. KEISER

JOHN W. KEKER

DUNCAN M. KENNEDY

JONATHAN L. KROWN

JOHN C. LADD

Thomas M. LeMberg

Daniel M. LEWIS

LINDSAY A. LOVEJOY, JR.

JOHN R. LUGAS, JR.
DAVID B. LYTLE

ANGus C. MACUETH

ROBERT D. MCLEAN

Ronald W. MEISTER

DAVID N. ROSEN

RAND E. ROSENULATT

BARRY A. SANDERS

THOMAS SCARLETT

Irving S. Schloss

MARTIN L. SENZEL

HOWARD F. SHATTUCK III

KENNETH I. SIDLE

STEVEN L. SLOCA

JAMES G. SPETH, JR.

ROBERT S. VENNING

GARY C. WALKER

MELVIN L. WATt

PETER H. WEINER

RICHARD A. ZIMMER

M. Olive Butterfield, Pamela Willmott

Student Contributors to This Issue

Paul R. Friedman, Scope Limitations for Searches Incident to Arrest

Raymond P. Boulanger, Public Utilities and the Poor: The Requirement

of Cash Deposits from Domestic Consumers

John W. Keker, Less Drastic Means and the First Amendment

Robert D. McLean, Tort Claims and the Bankrupt Corporation 